\title{
NEUTRONIC DESIGN OF URANIUM-PLUTONIUM NITRIDE FUEL-BASED GAS-COOLED FAST REACTOR (GFR)
}

\author{
S. Novalianda ${ }^{1 *}$, M. Ariani², F. Monado², Z. Su'ud ${ }^{3}$ \\ ${ }^{1}$ Study Program of Physics, Faculty of Mathematics and Natural Sciences, Universitas Sriwijaya, Indonesia \\ ${ }^{2}$ Department of Physics, Faculty of Mathematics and Natural Sciences, Universitas Sriwijaya, Indonesia \\ ${ }^{3}$ Study Program of Physics, Institut Teknologi Bandung, Indonesia
}

Received: 7 February 2018. Accepted: 28 May 2018. Published: 30 July 2018

\begin{abstract}
This study presents the calculation results of the cell, and core Gas-cooled Fast Reactor (GFR) based fuel UraniumPlutonium Nitride $(\mathrm{U}, \mathrm{Pu}) \mathrm{N}$. Parameter survey results of calculations of the fuel cell consisting of a $\mathrm{k}_{\text {inf }}$, burnup level, and the conversion ratio and for the calculation of the reactor core produce value $\mathrm{k}_{\text {eff }}$ during a refueling cycle. The calculation was performed by using a set of SRAC program by comparing three types of fuel cell designs. Reactor Design A based on natural uranium could not reach criticality because of $\mathrm{k}_{\text {eff }}<1$. Design B used the enrichment of uranium-235 by $9.5 \%$ to reach a critical condition at $k_{\text {eff }}>1$. The critical state was also achieved by Design $C$ utilizing natural uranium, and plutonium $5.5 \%$ result value $k_{\text {eff }}=1.015$ in the first year of burnup and continues to increase 1.083 in the tenth year without refueling. Moreover, plutonium can replace the uranium enrichment process.
\end{abstract}

\section{ABSTRAK}

Penelitian ini menyajikan hasil perhitungan sel dan teras gas-cooled fast reactor (GFR) berbasis bahan bakar UraniumPlutonium Nitride $(\mathrm{U}, \mathrm{Pu}) \mathrm{N}$. Parameter Survey untuk hasil perhitungan sel bahan bakar terdiri dari $\mathrm{k}_{\text {inf }}$, level burnup, dan conversion ratio. Sedangkan pada perhitungan teras reaktor dihasilkan nilai $\mathrm{k}_{\mathrm{eff}}$ untuk satu siklus pengisian bahan bakar. Perhitungan dilakukan dengan menggunakan seperangkat program SRAC dengan membandingkan tiga jenis desain sel bahan bakar yang berbeda. Reaktor Desain A berbasis uranium alam tidak mencapai kekritisan karena $\mathrm{k}_{\text {eff }}<1$. Desain $\mathrm{B}$ menggunakan pengayaan uranium-235 sebesar 9,5\% mencapai kondisi kritis pada $\mathrm{k}_{\text {eff }}>1$. Keadaan kritis juga dicapai oleh Desain C yang memanfaatkan uranium alam dan plutonium 5,5\% menghasilkan nilai $k_{\text {eff }}=1,015$ di tahun pertama burnup dan terus meningkat hingga 1,083 pada tahun kesepuluh tanpa pengisian ulang bahan bakar. Pemanfaatan plutonium sebagai bahan bakar dapat menggantikan proses pengayaan pada uranium.

Keywords: Burnup; Plutonium; Cell Core; Uranium

\section{INTRODUCTION}

The nuclear power plant is one of the energy sources to supply the electricity demand in Indonesia (Dewan Energi Nasional, 2014). The affordable operating cost and the absence of emission are the reason for the rapid growth of research and development in the nuclear power plant today (Giraldo et al., 2012). The attention on the development of Generation IV reactor, especially the helium Gas-cooled Fast Reactor (GFR) is needed presently (GIF, 2009). This GFR has a strength in its durability since it is operated in a closed fuel cycle using helium as a cooler. Also, it could

*Correspondence Address:

Jalan Padang Selasa 542, Palembang, Indonesia 30121 E-mail: sari_novalianda@yahoo.com produce the hydrogen gas at the temperature of $850^{\circ} \mathrm{C}$ (Kelly, 2014).

The source of heat energy of the nuclear reactor is the use of Uranium as fuel. Uranium generates the energy through the fission reaction is shown by the equation 1 (Su'ud \& Sekimoto, 2013)

$$
{ }_{0}^{1} n+{ }_{92}^{235} \mathrm{U} \rightarrow{ }_{54}^{140} \mathrm{Xe}+{ }_{38}^{94} \mathrm{Sr}+2{ }_{0}^{1} n+200 \mathrm{MeV}
$$

Uranium has three isotopes, i.e. U-238 (99.284\%), U-235 (0.711\%) and U-234 $(0.005 \%)$. U-235 is fissile and can create neutron directly. However, the amount of U-235 is limited; so that an enrichment process is needed to boost the atom density. Also, U-238 is fertile which potential to be converted as fissile fuel by absorbing neutron in a reaction (Rooi- 
jen, 2006).

The use of Uranium as a fuel of nuclear power plant will generate the electrical energy and side product at the end of its operation. The side product has a potency to be employed in another reactor to create more energy, for example, plutonium.

One of the fast reactor concepts to breed plutonium greater than its consumption is the Fast Breeder Reactor (FBR). Also, the waste of plutonium as a side product of FBR operation is beneficial as a fuel for other reactors (Walter \& Reynolds, 1981).

Plutonium is generated from the absorbing reaction of the neutron in Uranium-238. Uranium-238 absorbs the neutron to be Uranium-239 which is converted to be Neptunium-239 naturally, and finally, it generates Plutonium-239. The chain of Uranium-238 burnup is presented in Figure 1 (Duderstatd \& Hamilton, 1976).

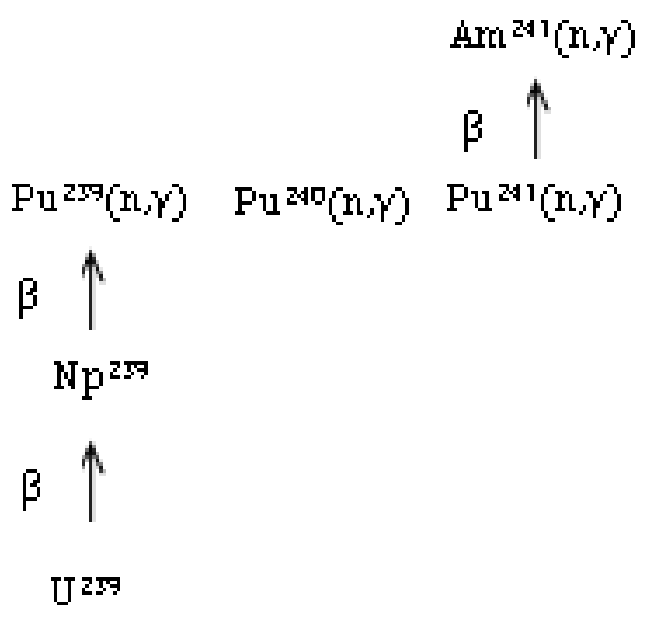

Figure 1. The chain of Uranium-238 burnup

The fission reaction of Uranium in a nuclear reactor generates five Plutonium dominant isotopes, i.e., Pu-238, Pu-239, Pu-240, $\mathrm{Pu}-241$, and Pu-242. Only Pu-239 and Pu-241 are fissile which could be employed as a fuel for other reactors (Meyer et al., 2007).

The most important aspect in designing a nuclear reactor is the neutron analysis which is related to the neutron behavior in the reactor core (Ariani et al., 2013). The description of the physical condition of the neutron in the reactor core is explained by the multi-group diffusion equation as follows (Stacey, 2007):

The equation 2 describes the neutron behavior including population, distribution, energy, velocity, density, and the average neutron flux at each energy level.

$$
\begin{aligned}
& \frac{1}{v_{g}} \frac{\partial \phi_{g}}{\partial t}-\nabla \cdot D_{\mathrm{g}} \nabla \phi+\Sigma_{\mathrm{tg}} \phi_{\mathrm{g}}(\mathrm{r}, t)= \\
& \sum_{\mathrm{g}=1}^{\mathrm{G}} \Sigma_{\mathrm{ag}_{\mathrm{g}} \mathrm{g}_{\mathrm{g}} \phi_{\mathrm{g}^{\prime}}}+x_{\mathrm{g}} \sum_{\mathrm{g}^{\prime}=1}^{\mathrm{G}} \mathrm{v}_{\mathrm{g}^{\prime}} \Sigma_{\mathrm{fg}_{\mathrm{g}}} \phi_{\mathrm{g}^{\prime}}+S_{\mathrm{g}^{\prime}} \phi_{\mathrm{g}}
\end{aligned}
$$

Neutron population along the operation of the reactor will affect the fuel management and the fuel reduction during the process which is calculated by the equation of burnup as follows (Duderstadt \& Hamilton, 1976).

$\frac{d N_{A}}{d t}=-\lambda_{A} N_{A}-\left[\sum_{g} \sigma_{A g}^{A} \phi_{g}\right] N_{A}+\lambda_{B} N_{B}+\left[\sum_{g} \sigma_{\lambda g}^{C} \phi_{g}\right] N_{C}$

Equation 3 is a burnup calculation related to the long-term change (day to the year) of the materials as a result of the nuclear reaction during the reactor operation. The burnup calculation is a basic of fuel management which consists of the calculation of reduction and isotope production as a function of time. Where $\lambda_{A} N_{A}$ represents the missing part as a result of radioactive decay, whereas $\left[\Sigma_{g} \sigma_{A g}^{A} \phi_{g}\right] N_{A}$ is a missing part because of neutron trapping, $\lambda_{B} N_{B}$ is the additional nuclead $A$ as a result of decay from $\mathrm{B}$ to $\mathrm{A}$, and $\left[\sum_{g} \sigma_{\lambda g}^{c} \phi_{g}\right] N_{C}$ is the change from $C$ to $A$ through neutron trapping.

Another analysis to determine the neutron population is influenced by the effective multiplication factor $\left(\mathrm{k}_{\text {eff }}\right)$, i.e.:

$\mathrm{k}_{\mathrm{eff}}=\frac{\text { jumlah neutron pada generasi sebelumnya }}{\text { jumlah neutron pada generasi sesudahnya }}$

Equation 4 has a rule of $k_{\text {eff }}=1$ called as a critical condition where the number of neutron remains constant. $\mathrm{k}_{\text {eff }}<1$ is a subcritical condition where there is a decline of neutron number. $k_{\text {eff }}>1$ is a supercritical condition where neutron number increases continually.

The objective of this research is to design the fast reactor GFR which can reach the critical condition, highly efficient, and durable. 


\section{METHOD}

Research stages were started by setting up the design parameter of GFR as shown in Table 1.

Table 1. The design parameter of GFR

\begin{tabular}{|c|c|}
\hline Parameters & Specification \\
\hline Thermal Power & $500 \mathrm{MWt}$ \\
\hline Fuels & $\begin{array}{l}\text { Uranium-Plutonium } \\
\text { Nitride (U, Pu)N }\end{array}$ \\
\hline Enrichment U-235 & $1-9.5 \%$ \\
\hline Plutonium & $1-5.5 \%$ \\
\hline Cladding & $\begin{array}{l}\text { Stainless Steel } \\
\text { (SS316) }\end{array}$ \\
\hline Coolant & Helium \\
\hline $\begin{array}{l}\text { Volume Fraction: } \\
\text { Fuel/Cladding/Cool- } \\
\text { ant }\end{array}$ & $60 \% / 10 \% / 30 \%$ \\
\hline $\begin{array}{l}\text { The diameter of pin } \\
\text { pitch }\end{array}$ & $1.4 \mathrm{~cm}$ \\
\hline Core geometry & Silinder \\
\hline $\begin{array}{l}\text { Height/ Width of the } \\
\text { active core }\end{array}$ & $350 \mathrm{~cm} / 240 \mathrm{~cm}$ \\
\hline Reflector thickness & $100 \mathrm{~cm}$ \\
\hline
\end{tabular}

Fuel cells consist of fuel, cladding, and coolant. Helium is one of the strong coolants compared to other inert coolants that cannot react with other matters (Novalianda et al., 2016).

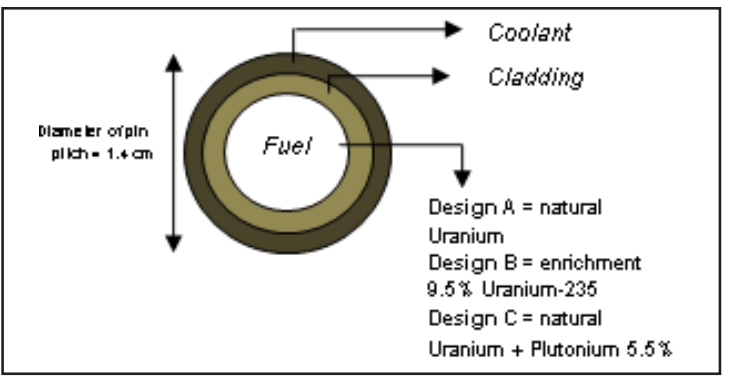

Figure 2. The geometry of the fuel cell

The fuel cell designed in this research were Design A with nature Uranium-based fuel cell, Design B with 9.5\% Uranium-235, and Design $\mathrm{C}$ with nature Uranium added by Plutonium $5.5 \%$. The geometry of the fuel cell is presented in Figure 2.

The mixture of fuel in the fast reactor which is based on the mixing of Uranium and Plutonium is Nitride. Nitride has a high melting temperature of $2500{ }^{\circ} \mathrm{C}$ and high thermal conductivity; thus, there is a possibility of obtaining the relatively lower temperature difference between the centers of fuel with the coolant. Nitride fuel is also flexible for fast reactors such as its high growing ratio, actinide burning, and the long-term terrace operation time (Meyer et al., 2007).

This research employed the program of Standard Reactor Analysis Code (SRAC) which has been developed by Japan Atomic Energy Agency (JAEA) since 1978 (Okumura et al., 2007). The flow diagram of the SRAC calculation can be seen in Figure 3.

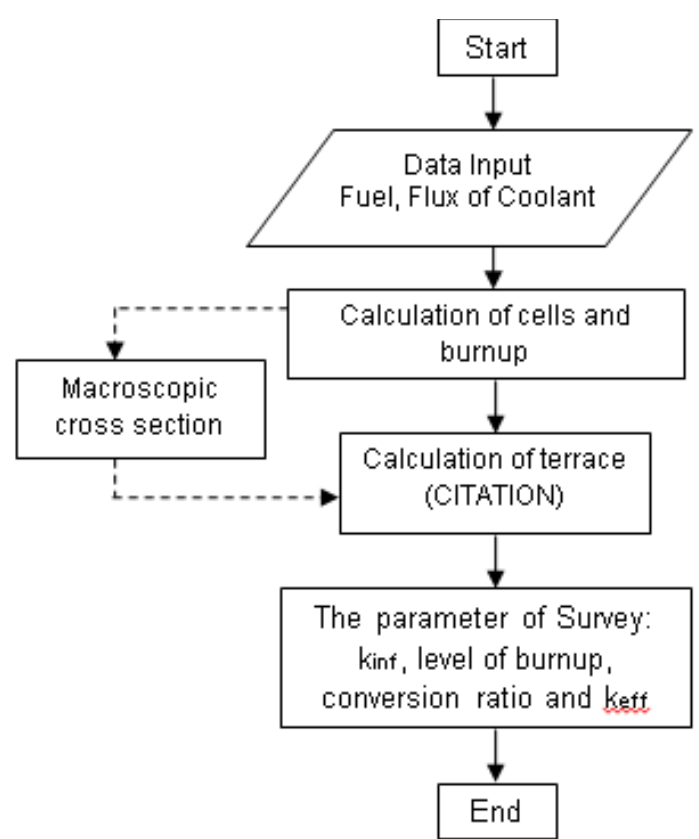

Figure 3. The calculation of the SRAC flow diagram

\section{RESULTS AND DISCUSSION}

SRAC calculation results in the GFR reactor were carried out by comparing the three reactor designs to the differences in fuel cells used. This fuel cell calculation is useful to determine the performance of one fuel cell for fifty years burnup so that it can later be used on the reactor core. Fuel cell calculations produce several survey parameters that have been determined, namely infinitive multiplication factor $\left(\mathrm{k}_{\mathrm{inf}}\right)$, burnup level and conversion ratio.

The first survey parameter is $\mathrm{k}_{\text {inf. }} \mathrm{k}_{\mathrm{inf}}$ states the size of the increase or decrease in neutron flux, which is calculated in the absence of a leak factor (Hangbok et al., 2008). Changes in the $\mathrm{k}_{\mathrm{inf}}$ value to the burnup time are shown in Figure 4. 


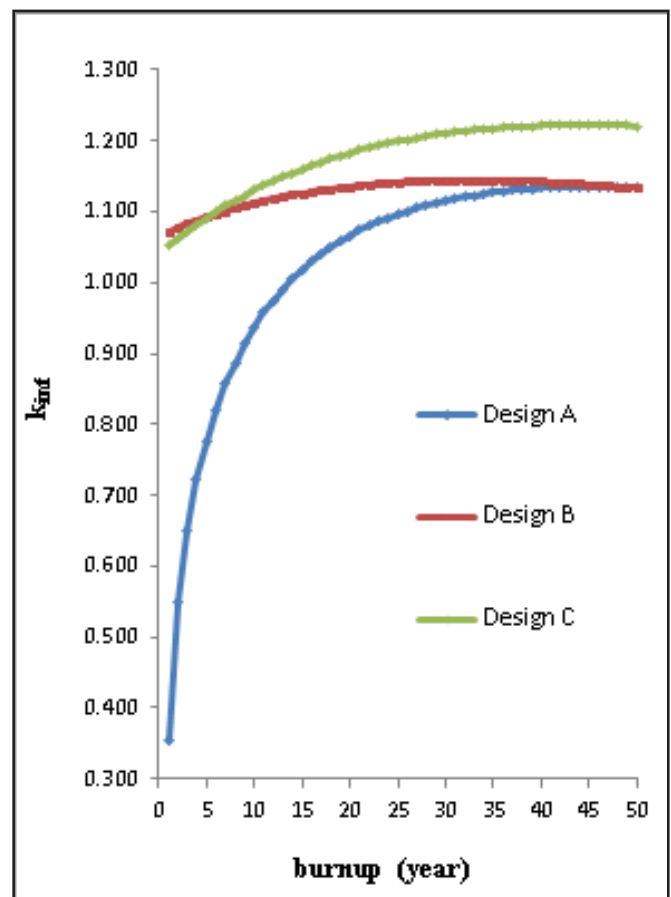

Figure 4. Infinitive multiplication factor $\left(\mathrm{k}_{\text {inf }}\right)$ to the change of burnup time

The Design A in Figure 4 shows the initial burnup $\mathrm{k}_{\text {inf }}$ value under the critical condition of $0.353\left(k_{\text {inf }}<1\right)$ because the number of neutrons produced is relatively small. It is because the fuel cell used is natural Uranium which has a fissile density of only $0.7 \%$ of the total. However, as time goes by, the critical condition can be achieved in the fourteenth year with a $k_{\text {inf }}$ value of 1.005 . The increase in $k_{\text {inf }}$ occurs along with the increase in fission products generated during increased burnup time. Reactor criticality can be achieved in Design $B$ and $C$ with $k_{\text {inf }}$ values at 1.071 and 1.076, respectively. Design B using Uranium-235 enrichment produced a fissile density of $9.5 \%$, which means an increase of fissile material as much as $9.5 \%$ from the original $0.7 \%$. This increase results in more neutrons produced than used neutrons. Likewise with Design C that uses plutonium at $5.5 \%$, can reach critical conditions in the first year of burnup.

Burnup is defined as the total energy released per unit mass of fuel as a result of fuel combustion (Monado et al., 2013). Figure 5 shows the change in burnup level over burnup time, where the burnup level value continues to increase as burnup time increases. The burnup level value for Design A in the fiftieth year is $167 \mathrm{GWd} /$ ton, meaning that in 1 ton of uranium fuel produces $167 \mathrm{GW}$ of energy per day.
Design $B$ also produces the same burnup level value as Design $A$, because the same fuel used is uranium. However, if each design is further examined, the average results are different. For example, Design $A$ has a value of $0.085 \mathrm{GWd} /$ ton and Design B at $0.084 \mathrm{GWd} /$ ton. Moreover, Design $C$ burnup level value is $161 \mathrm{GWd}$ /ton with average $0.082 \mathrm{GWd} / \mathrm{ton}$, where the value is smaller than the other two designs due to differences in the composition of the atom density input.

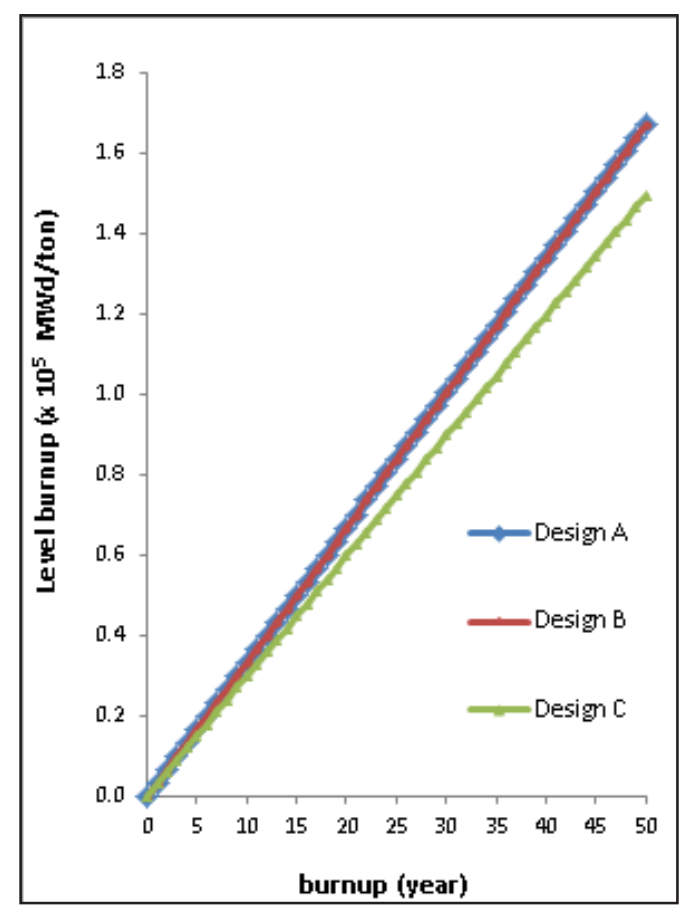

Figure 5. The change in burnup level

The conversion ratio $(\mathrm{CR})$ states the ratio of the amount of fissile material produced with the fissile material consumed as shown in Figure 6. Design A, it shows the sharp decline of CR from 14.6 to 1.53. It is due to Design A which uses natural uranium with the fissile material used by $0.7 \%$ which is far less than the amount of its material. The decrease of $C R$ value indicates that the breeder of fissile material will continue to decrease during burnup time because the number of neutrons produced will be far less than the neutrons used.

Design B has a CR value $<1$ (0.99 to $0.95)$ which means that the reactor consumes more fissile material than the other designs. It is due to the reduced amount of Uranium-238 as a result of the enrichment of Uranium-235 by $9.5 \%$. Nuclear reactors which are projected to be breeding reactors must have a CR value $>1$ (Walter, \& Reynolds, 1981). Thus, the reac- 
tor only requires the intake of fertile material to be converted into fissile material. Furthermore, in Design C, the value of CR > 1 (1.79 to 1.24) due to two fissile materials used at the beginning of burnup namely Uranium-235 and Plutonium-239 so that the amount of fissile produced is much higher than the amount of fissile used.

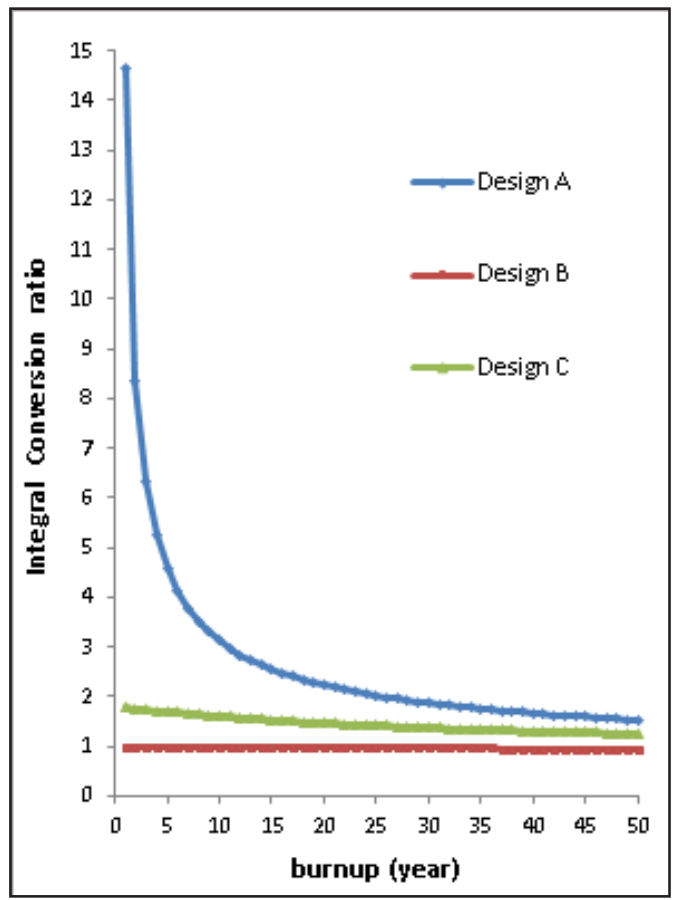

Figure 6 . The change in conversion ratio to the burnup time

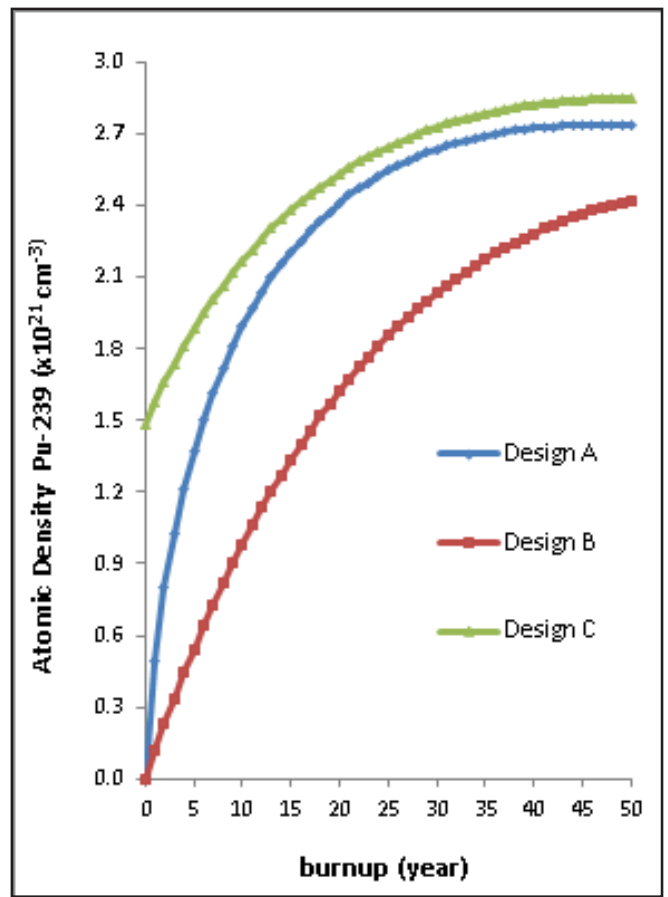

Figure 7. The change of Plutonium-239 atom density to burnup time.
During the burnup process, Uranium-235 will change to other elements. Likewise with Uranium-238 which is fertile will change into another element due to the fission reaction that occurs in the fuel cell. One of the fission products produced from Uranium-238 is Plutonium-239 (Figure 1). As shown in Figure 7, Design $A$ has the change in density of Plutonium-239, which at the beginning of the fission reaction does not yet exist, until the burnup process runs. Plutonium-239 is created and will increase as long as the burnup process lasts for $2.7 \times 10^{21}$ barn $/ \mathrm{cm}$. In Design B, the amount of Plutonium-239 will decrease to the $2.1 \times 10^{21}$ barn/cm proportionally with the decrease in Uranium-238 density as a result of Uranium-235 enrichment used. Besides, the Design $\mathrm{C}$ shows the addition of Plutonium at the beginning of burnup process as much as $1.3 \times 10^{21}$ barn/cm and will continuously increase the density of Plutonium-239 atom at the end of burnup time to the $2.1 \times 10^{21} \mathrm{barn} / \mathrm{cm}$.

Another design of GFR during burnup process shows the density of Plutonium-239 that has not been generated up to the tenth year of burnup time, due to Nitride Uranium natural fuel availability or without Uranium-235 enrichment done (Ariani et al., 2013).

The results of the calculation of the fuel cell will be used for the calculation of the reactor core, where the reactor core is composed of a collection of several fuel cells. This core calculation is carried out in one fueling cycle for ten years without refueling. The survey parameters observed were effective multiplication factors $\left(\mathrm{k}_{\text {eff }}\right)$, namely the ratio of the number of neutrons from one generation to neutrons in the next generation (Liem et al., 2008).

Figure 8 shows the change in $\mathrm{k}_{\text {eff }}$ value to burnup time. Design A has $\mathrm{k}_{\text {eff }}$ value $<1$ that is 0.332 in the first year burnup, then the reactor has not reached its critical condition. Design $B$ reactor has reached a critical state with $\mathrm{k}_{\text {eff }}$ value $>1(1.008$ to 1.051$)$ with an excess reactivity of $0.031 \%$.

According to Su'ud and Sekimoto (2013), the criticality of the GFR reactor was also achieved in the GFR design with $800 \mathrm{MWt}$ of uranium nitride fueled power using a CANDLE burnup strategy yielding a $\mathrm{k}_{\text {eff }}$ value of $>1$ (1.002 to 1.007). Other studies on the GFR reactor design can also reach critical conditions at $\mathrm{k}_{\text {eff }}>$ 1 (1.001 to 1.050 ) using natural nitride uranium for ten years of refueling (Ariani et al., 2013). 


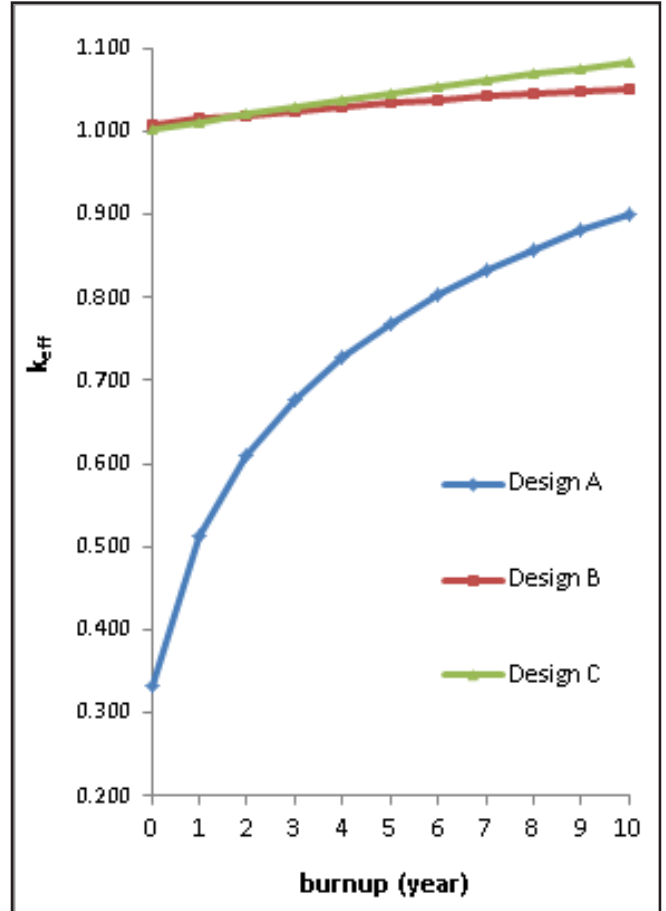

Figure 8. Effective multiplication factor $\left(\mathrm{k}_{\text {eff }}\right)$ to burnup time change

Excess reactivity states that there is an excess reactor reactivity due to an increase in $\mathrm{k}_{\text {eff }}$ value in the reactor core. In Design $\mathrm{B}$, even though it reaches the critical condition of the reactor with a $\mathrm{k}_{\text {eff }}$ value $>1$; however, the CR value is $<1$ as shown in Figure 6 . It means that the amount of fissile material produced is smaller than its consumption. This condition implies that the increase in burnup time, the fuel used will run out. Based on Design $\mathrm{C}$, the reactor also reached the critical state at $\mathrm{k}_{\text {eff }}>1$ (1.015 to 1.083 ) with $0.047 \%$ excess reactivity. This reactor can continue to operate due to the ratio of neutrons produced to the neutrons used is $>1$.

\section{CONCLUSION}

The design of ( $\mathrm{U}, \mathrm{Pu}) \mathrm{N}$ fuel-based GFR with a volume fraction consisting of $60 \%$ fuel, $10 \%$ cladding and $30 \%$ coolant produced a $\mathrm{k}_{\text {eff }}$ value $>1$ (1.015 to 1.083$)$ with an excess reactivity of $0.047 \%$. This reactor can operate for 10 years without a refueling process due to the ratio of neutrons produced to the neutrons consumed is $>1$. The fission product of Uranium-238 is Plutonium-239 which can be reused as reactor fuel. The use of plutonium as a fuel can replace the enrichment process in Uranium-235.

\section{REFERENCES}

Ariani, M., Su'ud, Z., Monado, F., Waris, A., Khairurrijal, Arif, I., Aziz, F., \& Sekimoto, H. (2013). Optimization of Small Long Life Gas Cooled Fast Reactors with Natural Uranium as Fuel Cycle Input. Applied Mechanics and Materials, 260-261, pp 307-311.

Dewan Energi Nasional Republik Indonesia. (2014). Outlook Energi Indonesia 2014.

Duderstadt, J.J., \& Hamilton, L.J. (1976). Nuclear Reactor Analysis. Department of Nuclear Engineering, The University of Michigan, Ann Arbor Michigan. JOHN WILEY \& SONC, Inc.

GIF. (2009). GIF R\&D Outlook For Generation IV Nuclear Energy Systems.Giraldo, S. J., D.J. Gotham., D.G. Nderitu., P.V. Preckel., \& D.J. Mize. (2012). Fundamentals of Nuclear Power. State Utility Forecasting Group.

Hangbok, C., Rimpault, G., \& Bosq, J.C. (2006). A Physics Study of a 600-MW (thermal) Gascooled Fast Reactor. Nuclear Science and Engineering.152(2), 204-218.

INTERNATIONAL ATOMIC ENERGY AGENCY (IAEA). (1999). Minimization of Waste from Uranium Purification, Enrichment and Fuel Fabrication, IAEA-TECDOC-1115, Vienna.

Kelly, E. J. (2014). Generation IV International Forum: A decade of progress through international cooperation. Progreess in Nuclear Energy. $77,240-246$.

Laidler, K.J. (1993). The World of Physical Chemistry. Oxford University Press, Oxford.

Liem, P.H., Ismail, \& Sekimoto, H. (2008). Small high temperature gas-cooled fast reactor with innovative nuclear burning. Progress in Nuclear Energy. 50 (2-6), 251-256.

Meyer, K. M., Fielding, R., \& Gan, J. (2007). Fuel development for gas-cooled fast reactors. Journal of nuclear materials. 371, 281-287.

Monado, F., Z. Su'ud., A. Waris., K. Basar., M. Ariani \& H. Sekimoto. (2013). Application of Modified CANDLE Burnup to Very Small Long Life Gas-cooled Fast Reactor. Advanced Materials Research. 772, 501-506.

Novalianda, S., Ariani, M., Monado, F., \& Su'ud, Z. 2016. Studi Awal Perhitungan Sel Bahan Bakar Berbasis Uranium Oksida $\left(\mathrm{UO}_{2}\right)$ Pada Reaktor Cepat Berpendingin Helium. Jurnal Lingkungan dan Pembangunan (Enviroment and Development). 2(1), ISSN 0216-2717.

Okumura, Teruhiko K., Kunio, K., \& Keichiro, T. (2007). SRAC2006: A Comprehensive Neutronic Calculation Code System. Japan Atomic Energy Agency.

Rooijen, V. (2006). Improving Fuel Cycle Design and Safety Characteristics of a Gas Cooled Fast Reactor. IOS Press.

Stacey, M. W. (2007). Nuclear Reactor Physics. Second Edition, Completely Revised and Enlarged. WILEY-VCH Verlag GmbH \& Co. $\mathrm{KGaA}$. 
Su'ud, Z., \& Sekimoto, H. (2013). The prospect of gas cooled fast reactors for long life reactors with natural uranium as fuel cycle input. $A n$ nals of Nuclear Energy. 54, 58-66.

Su'ud, Z., Arbie, B., \& Sedyartomo (2005). The Prospect of MOX Fuel Based Pb-Bi Cooled
Small Nuclear Power Reactors'. Progress of Nuclear Energy. 47, 212-221.

Walter, E.A., \& Reynolds, A. B. (1981). Fast Breeder Reactors. PERGAMON PRESS. New York/ Oxford/ Toronto/ Sydney/ Paris/ Frankfurt. 